\title{
Risk Factors for Nosocomial Infections in Children
}

\section{Çocuklarda Nozokomiyal Enfeksiyonlar İçin Risk Faktörleri}

\author{
๑Tülin Çataklı1, ๑Aysel Yöney² \\ 'Lokman Hekim Hospital, Division of Pediatrics, Ankara, Turkey \\ ${ }^{2}$ Dr. Sami Ulus Children's Hospital, Ankara, Turkey
}

\begin{abstract}
Aim: To determine the frequency of healthcare associated infections (HCAls) developed within a year in patients admitted to a tertiary pediatric hospital.

Material and Method: Between February 1996 January 1997 the patients hospitalized at Dr Sami Ulus Children's Hospital and diagnosed as HCAI during their follow up were included in the study. The diagnosis of 'nosocomial infection' was made on the basis of Center for Disease Control (CDC) diagnostic criteria . Clinical, laboratory and imaging findings were recorded.
\end{abstract}

Results: HCAls were detected in 311 (9.1\%) of the 3420 hospitalized patients. Some of these patients experienced more than 1 episode, and thus, the total HCAl episodes were 353. Of the patients with HCAl; $77.8 \%$ were younger than 1 year old, $60.5 \%(n=188)$ were male. HCAl was detected to occur after $10.9 \pm 10$ days of hospitalization. The most frequent HCAls were acute gastroenteritis, sepsis, urinary tract infections and lower respiratory system infections. Gram-negative organisms were the most frequently isolated agents. Of the 311 patients with HCAls, 38 (12.2\%) died.

Conclusion: HCAI is an important cause for mortality and morbidity in pediatrics clinics. HCAI surveillance, detection of the problems and taking precautions for infection control are important steps.

Keywords: Health care-associated infections, child, risk factors
Öz

Amaç: Üçüncü basamak bir çocuk hastanesine yatırılan hastalarda bir yıllık süre içinde gelişen sağlık bakımı ile ilişkili enfeksiyon (SBIE) sıklığının belirlenmesidir.

Gereç ve Yöntem: Şubat 1996 - Ocak 1997 tarihleri arasında Dr. Sami Ulus Çocuk Hastanesine yatırılan ve izlemlerinde SBIE tanısı alan hastalar çalışmaya alındı. SBIE tanısı, CDC (Center for Disease Control and Prevention) tanı kriterleri esas alınarak konuldu. Klinik kayıtlar, laboratuar ve görüntüleme bulguları kaydedildi.

Bulgular: Hastaneye yatıılan 3420 hastada $311(\% 9,1)$ SBIE saptandı. Bu hastalardan bazılarında 1'den fazla enfeksiyon epizotu saptandı.Toplam SBIE epizodları 353 idi. Olguların $\% 77,8$ i bir yaş altında, \%60,5 ( $n=188)$ erkek idi. SBIE yatıştan sonraki 10,9 10 günlerde ortaya çıktığı saptandı. En sık görülen SBIE; akut gastroenterit, sepsis, üriner sistem enfeksiyonu ve alt solunum yolu enfeksiyonları idi. Gram negatif organizmalar en sık izole edilen ajanlardı. SBIE tanısı alan 311 hastanın 38' kaybedildi $(\% 12,2)$.

Sonuç: SBIE çocuk servislerinde önemli mortalite ve morbidite nedenidir. SBIE sürveyansı sorunların saptanması ve enfeksiyon kontrolü için önlemler alınması çok önemli basamaktır.

Anahtar Kelimeler: Sağılk bakımı ilişkili enfeksiyon, çocuk, risk faktörler 


\section{INTRODUCTION}

Hospital-acquired infections (HCAl), also known as healthcareassociated infections (HCAl), are nosocomially acquired infections that are typically not present or might be incubating at the time of admission. These infections are usually acquired after hospitalization and manifest 48 hours after admission to the hospital. HCAls can happen in any health care facility, including hospitals, ambulatory surgical centers, end-stage renal disease facilities, and long-term care facilities. Bacteria, fungi, viruses, or other, less common pathogens can cause HCAls. HCAls are a significant cause of illness and death and they can have serious emotional, financial, and medical consequences. ${ }^{[1,2]}$ Patients hospitalized in pediatric services and pediatric intensive care units (PICUs) have a higher risk of HCAls. Prolonged hospitalization, invasive interventions, congenital malformations, and total parenteral nutrition are significant factors that increase the risk of nosocomial infections in pediatric patients. Prolonged hospitalization, invasive interventions, congenital malformations, and total parenteral nutrition are significant factors that increase the risk of HCAl in pediatric patients.The incidence, prevalence, morbidity and mortality rates of HCAls varies depending on factors such as the type of the hospital, age of the patient, diagnosis at hospitalization, hospitalization service, diagnosis and treatment interventions. ${ }^{[3]} \mathrm{HCAls}$ are a frequent problem, particularly in Intensive Care Units (PICU). In Europe, incidence of nosocomial infections was reported as $1-2.5 \%$ in general pediatric services and as $6.1-15.1 \%$ in pediatric intensive care units (PICU). ${ }^{[4,5]}$ In developing countries, HCAI rates of PICUs were reported - much higher 13.6-15.4\%. ${ }^{[7,8]}$

Healthcare-associated infection is to be a significant cause of morbidity and mortality worldwide and in Turkey. HCAI frequency is reported as $3.02 \%$ to $9.3 \%$ in the pediatric age group in Turkey. ${ }^{[3,9]}$ Since 2005 every hospital has "National Nosocomial Infections Surveillance and Control Unit". ${ }^{[10]}$ Since then there has been significant decrease in HCAI rates, where the particular decrease in year 2007 should be noted. ${ }^{[3]}$

The aim of this research is to find out the frequency of nosocomial infections in one year period in Dr. Sami Ulus Pediatric Hospital and to compare the changes in surveillance studies of nosocomial infections in children in different years with the derived data.

\section{MATERIAL AND METHOD}

In the present study, the data of healthcare-associated infections detected at Dr. Sami Ulus Children's Training and Research Hospital -a tertiary hospital-, were collected in the period January 1996- December 1996. The pediatric hematology-oncology service was excluded from the study. The diagnosis of Healthcare-associated infections (HCAl) have been assessed according to the Centers for Disease Control and Prevention (CDC) criteria. For HCAls, questionnaires included information on the type of infection, onset of infection, any device relationship (e.g. whether a urinary catheter had been fitted before onset of infection), and other details. Information on whether the nosocomial infection had already been present on admission or had been acquired during the current hospital stay, and the pathogen that had caused the infection, were also recorded. Culture samples obtained from patients were studied in the microbiology laboratory using traditional manual methods. Infection sites, responsible microorganisms and their effect on prognosis were studied. For prophylactic antibiotic use, the type of antibiotic, route of administration, indication, and whether the indication was listed in the patient's medical record were recorded. The Statistical Package for the Social Sciences (SPSS) for Windows version 10.1 was used for the statistical analysis. The study was approved by the Ethics Committee of Dr.Sami Ulus Maternity and Children's Training and Research Hospital, Ankara, Turkey (Date: 17.01.2020, No:73799008).

\section{RESULTS}

In the 1-year period, 3420 patients were hospitalized. HCAls were detected in 311 (9.1\%) of the patients. Thirty-eight (13.5\%) of these patients experienced more than 1 episode, and thus, the total number of HCAl episodes was 353. 39.5\% ( $n=123)$ of the patients were female and $60.5 \%(n=188)$ of them were male. The relationship between gender and HCAl was found statistically significant $(p<0.05) .77 .8 \%$ of the patients were younger than 1 year of age. HCAl frequency was higher in the $0-1$-year-old age group than the other age groups. This difference was found statistically significant $(p<0.05)$ (Table 1$)$.

\begin{tabular}{|c|c|c|c|c|c|}
\hline Diagnosis / age & $\begin{array}{c}0-12 \\
\text { months }\end{array}$ & $\begin{array}{l}1-4 \\
\text { age }\end{array}$ & $\begin{array}{l}5-9 \\
\text { age }\end{array}$ & $\begin{array}{c}10-14 \\
\text { age }\end{array}$ & $\begin{array}{l}\text { Total } \\
\text { n (\%) }\end{array}$ \\
\hline Gastroenteritis & 79 (88.7) & $9(10.1)$ & $1(1.2)$ & & $89(28.6)$ \\
\hline Sepsis & $67(84.8)$ & $9(11.3)$ & $2(2.5)$ & $1(1.2)$ & $79(25.4)$ \\
\hline Urinary tract infection & $61(83.6)$ & $12(16.4)$ & & & $73(23.4)$ \\
\hline Pneumonia & $20(51.2)$ & $9(23.0)$ & 7 (17.9) & $3(7.7)$ & $39(12.5)$ \\
\hline Peritonitis & & & $3(30.0)$ & $7(70.0)$ & $10(3.2)$ \\
\hline Omphalitis & $9(100.0)$ & & & & $9(2.8)$ \\
\hline Skin infection & $3(42.8)$ & $4(57.1)$ & & & $7(2.2)$ \\
\hline Conjunctivitis & $3(60.0)$ & $2(40.0)$ & & & $5(1.6)$ \\
\hline Total, n (\%) & $242(77.8)$ & $44(14.1)$ & $13(4.1)$ & $12(3.8)$ & $311(100.0)$ \\
\hline
\end{tabular}

HCAl distribution in terms of diagnosis was as follows: $28.6 \%$ $(n=89)$ of them were $G E, 25.4 \%(n=79)$ were sepsis, $23.4 \%$ $(n=73)$ were UTI, $12.5 \%(n=39)$ were pneumonia, $3.2 \%(n=10)$ were peritonitis, $2.8 \%(n=9)$ were omphalitis, $2.2 \%(n=7)$ were skin infection and $1.6 \%(n=5)$ were conjunctivitis. HCAI-GE was high because of the Salmonella Gastroenteritis epidemic during May-June period.

Patients were diagnosed with $\mathrm{HCAl}$ on the average of $10.9 \pm 10^{\text {th }}\left(383^{\text {rd }}\right)$ day of their hospitalization - in HCAI-Sepsis it was $16.1 \pm 6.7$, urinary tract infection $19.2 \pm 13.1$, pneumonia $22.8 \pm 13.9$ and GE $14.6 \pm 8.9$ days. Although the day of diagnosis for HCAls differed, this was not found statistically significant $(p>0.05)$. 
Table 2. Distribution of the causative microorganisms of HCAI

\begin{tabular}{lcc} 
& $\mathbf{n}$ & $\%$ \\
\hline Klebsiella spp. & 99 & 40.2 \\
Salmonella spp. & 58 & 23.5 \\
E. coli & 29 & 11.7 \\
CoNS & 14 & 5.6 \\
S. aureus & 8 & 3.2 \\
Pseudomonas spp. & 10 & 4.0 \\
Candida & 8 & 3.2 \\
Enterococcus spp. & 7 & 2.8 \\
Enterobacter spp. & 7 & 2.8 \\
Group B streptococcus & 6 & 2.4 \\
Total & 246 & 100 \\
\hline CoNs: Coagulase negative staphylococcus & & \\
\hline
\end{tabular}

The comorbid diseases were malnutrition $50.4 \%(n=178)$, congenital heart diseases $17.5 \%(n=62)$, Immunodeficiency $15.8 \%(n=56)$, chronic kidney disease (CKD) $2.8 \%(n=10)$ and neuromuscular disease $1.4 \%(n=5)$. Nine of HCAI-Peritonitis cases $(n=10)$ were the patients who were applied continuous ambulatory peritoneal dialysis (CAPD) because of CKD. Existence of CAPD in Peritonitis cases was found to be statistically significant $(p<0.05)$.

The HCAl diagnosis was established by clinical features in 107 (34.4\%) patients whose cultures were negative or not available. Various organisms were isolated in 246 (69.6\%) of the cultures in the 353 HCAls episodes. Gram-negative organisms were more frequently isolated (58.9\%) than Gram positive- organisms (41.0\%). The most frequently isolated organisms were Klebsiella spp. 99 (40.2\%), Salmonella spp. 58 (23.5\%), E. coli 29 (11.7\%), coagulase-negative staphylococcus (CoNS) 14 (5.6\%), Pseudomonas aeruginosa 10 (4\%), Candida 8 (4.0\%), Enterococcus spp. 7 (2.8\%), Enterobacter spp. 7 (2.8\%) and Grub B Streptococcus 6 (2.4\%).

When the distribution of detected organisms and infection site was examined, in HCAl-sepsis and UTI cases, the most frequently detected agent was K. pneumonia. In HCAI-UTI cases, E. coli was the second most frequently detected agent. In all of the culture-positive HCAI-GE cases, Salmonella spp was detected as the agent (Table 3).
In vitro antibiotics susceptibility of the isolated microorganisms were as follows: Klebsiella spp; amikasin $45 \%$, sulperazon 59\%, Escherichia spp; sulperazone $45 \%$, seftriakson $60 \%$, Salmonella spp.; amikasin and netilmisin 45\%, P. aeruginosa; sulperazone $56 \%$, netilmicin sulfate $49 \%$, S. aureus; vancomycin $80 \%$, CoNS; ceftazidime $55 \%$. Grub B Streptococcus was found susceptible to Amoxycillin- Clavulanic Acid with the ratio of $80 \%$. In all agents, imipenem susceptibility was $100 \%$.

Thirty-eight of the 311 patients (12.2\%) died. 32 of them were HCAl-sepsis and 6 of them were HCAl-pneumonia. 14 of the patients who died of sepsis were the premature newborns who had been hospitalized in neonatal intensive care unit (NICU). In NICU, premature newborn mortality was $28.5 \%$ (14/49) and term neonatal was $12.1 \%$ (5/41).

During the period that this research was conducted, in the services, there was 1 washbasin in every room and no isolation room in any of the services. During daytime working hours there was 1 nurse per 6-7 patients and 1 nurse per 15-20 patients during nighttime working hours.

\section{DISCUSSION}

Healthcare-associated infections (HCAls), or nosocomial infections, are a significant cause of morbidity and mortality. HCAl surveillance is important for effective infection control. [12,13] The frequency of HCAls varies according to the type of hospital. The rates have been determined as $4.4 \%$ in primary care hospitals; $7.1 \%$ in tertiary care hospitals and $19.2 \%$ in intensive care units. ${ }^{[14]}$ In our study, the HCAls rate was found to be $9.1 \%$. During the period of our study, in the studies of Campins et al. ${ }^{[15]}$ from Spain, and Starling et al. ${ }^{[16]}$ from Brasil, the frequency of nosocomial infection was reported as $9.7 \%$ and $10.2 \%$, respectively. In 2009 , Özçetin et al. ${ }^{[9]}$ reported the frequency of HCAls as $5,3 \%$ in the pediatric service of the university hospital (excluding the neonatal service) covering a one year period. In the study of Maraş et al. ${ }^{[17]}$ published in 2015, the frequency of nosocomial infection was reported as $9.3 \%$. Although studies have been conducted in different countries and in different years, the HCAl rate in pediatric services is similar.

Table 3. The distribution of the detected organisms according to the infection site

\begin{tabular}{|c|c|c|c|c|c|c|c|c|c|}
\hline \multirow[b]{2}{*}{ HCAI-microorganisms } & \multicolumn{9}{|c|}{ The HCAI-Site } \\
\hline & $\begin{array}{c}\mathrm{GE} \\
(n=89)\end{array}$ & $\begin{array}{l}\text { Sepsis } \\
(n=79)\end{array}$ & $\begin{array}{c}\text { Pneumonia } \\
(n=39)\end{array}$ & $\begin{array}{c}\text { UTI } \\
(n=73)\end{array}$ & $\begin{array}{c}\text { Peritonitis } \\
(n=10)\end{array}$ & $\underset{(n=9)}{\text { Omphalitis }}$ & $\begin{array}{c}\text { Skin infection } \\
(n=7)\end{array}$ & $\underset{(n=5)}{\text { Conjunctivitis }}$ & Total \\
\hline Klebsiella spp. & & 43 & & 41 & 4 & 9 & & 2 & 99 \\
\hline Salmonella spp. & 58 & & & & & & & & 58 \\
\hline CoNS & & 4 & 1 & & 4 & 3 & & 2 & 14 \\
\hline S. aureus & & 2 & 2 & & 2 & & 2 & & 8 \\
\hline Candida & & & & 3 & & & & & 8 \\
\hline Enterococcus spp. & & 3 & & 4 & & & & & 7 \\
\hline Enterobacter spp. & & 2 & & 5 & & & & & 7 \\
\hline Group B streptococcus & & 2 & & 4 & & & & & 6 \\
\hline
\end{tabular}


The frequency of the HCAls in children is inversely correlated with age. ${ }^{[18]}$ It was found in our study that approximately $2 / 3$ of the HCAl cases were under twelve months. HCAl incidence in the pediatric intensive care unit (PICU) was high: long-term monitoring, invasive interventions, total parenteral nutrition, and the use of high-spectrum antibiotics are factors that increase the risk of infection among patients who are treated and monitored in pediatric clinics, especially in PICUs. ${ }^{[20]}$ In our study, $28.9 \%$ of all HCAls were detected in the neonatal intensive care unit. In parallel with the findings of earlier studies, the frequency of nosocomial infections was highest in our study among PICU patients. ${ }^{[21]}$

In our study, the most frequently observed HCAls were bloodstream infections, urinary tract infections and pneumonia when Salmonella gastroenteritis in May and June is excluded.

HCAI microorganisms differ between the hospitals and in different units within the same hospital. ${ }^{[4,22]}$ In our study, gram negative bacilli such as Klebsiella spp., Salmonella spp. and E. coli were detected as responsible in more than half of the HCAl cases. The results of our study are similar to those of studies conducted in following years in Turkey. ${ }^{[3,9,23,24]}$ In our study, common HCAls-microorganisms were detected to have low susceptibility to aminoglycoside and third-generation cephalosporins. This situation was thought to be related to the frequent preference of these antibiotics in empirical treatment or to Extended-Spectrum Beta-Lactamases (ESLB) Producing Escherichia coli and Klebsiella spp. All of the microbiological agents were detected as highly susceptible to imipenem (100\%). Since carbapenems (imipenem) were not widely used during the years of our study, it was thought that they were highly susceptible especially against ESLBs.

In our study, $12.2 \%$ of HCAls cases ( $n=311$ ) died. All of these cases had risk factors that facilitated the development of infection (Age, male gender, congenital heart disease, Chronic Kidney Disease, malnutrition, prematurity). Kepenekli et al. ${ }^{[24]}$ found that HCAls cause considerable morbidity and mortality in pediatric intensive care units (PIUCs). The research indicates that the mortality rate of HCAls in PICUs is $13 \%$. Similar findings about mortality and morbidity were noted in our study.

The number of patients per nurse and nurse care are important in preventing HCAls. ${ }^{[25]}$ Özçetin et al. ${ }^{[9]}$ reported in their study that as the number of patients per nurse increased, the frequency of HCAl increased. In our hospital during daytime working hours there was 1 nurse per 6-7 patients and 1 nurse per 15-20 patients during nighttime working hours. The relationship between the number of patients per nurse and the state of HCAl development has not been evaluated.

It is not easy to determine the additional costs that HCAls bring to hospitals. Annually, approximately 2 million patients suffer with healthcare-associated infections (HCAls) in the USA, and nearly 90,000 are estimated to die. The overall direct cost of HCAls to hospitals ranges from US $\$ 28$ billion to 45 billion. ${ }^{[26]}$ In our country, the studies conducted by Yalçın et al. ${ }^{[27]}$ had reported that the duration of hospital stay due to nosocomial infection increased by 20 days per patient and the cost per patient increased by 1582 dollars. Carbapenem antibiotics (imipenem) were generally used in our study due to low susceptibility to other antibiotics. In the one year period, the additional cost of the antibiotics alone was calculated as about 75000 USD.

\section{CONCLUSION}

Healthcare-acquired infections (HCAls) are significant causes of mortality and morbidity, and may lead to prolonged hospitalization as well as increased costs throughout the world. The surveillance of HCAls may help in decreasing the incidence of infections and reducing costs.

\section{ETHICAL DECLARATIONS}

Ethics Committee Approval: University of Health Sciences, Dr Sami Ulus Maternity and Children's Education and Research Hospital Evaluation Committee approval was obtained for this study (approval number: 73799008/ 17-012020)

Informed Consent: Because the study was designed retrospectively, no written informed consent form was obtained from patients.

Referee Evaluation Process: Externally peer-reviewed.

Conflict of Interest Statement: The author(s) declared no potential conflicts of interest with respect to the research, authorship, and/or publication of this article.

Financial Disclosure: The authors declared that this study has received no financial support.

Author Contributions: All of the authors declare that they have all participated in the design, execution, and analysis of the paper, and that they have approved the final version.

\section{REFERENCES}

1. Boev C, Kiss E. Hospital-Acquired Infections:Current Trends and Prevention. Crit Care Nurs Clin North Am 2017;29(1):51-65.

2. The burden of health care-associated infection worldwide, World Health Organization Web site. Available at:http://www.who.int/gpsc/ country_ work/burden_hcai/en. Accessed April 8, 2021.

3. Balaban I,Tanır G, Metin Timur O, et al. Nosocomial Infections in the General Pediatric Wards of a Hospital in Turkey. Jpn J Infect Dis 2012;65:318-21.

4. Raymond J, Aujard Y, and the European Study Group. Nosocomial infections in pediatric patients:a European, multicenter prospective study. Infect Control Hosp Epidemiol 2000;21:260-3.

5. Urrea M, Pons M, Serra M, Latorre C, Palomeque A. Prospective incidence study of nosocomial infections in a pediatric intensive care unit. Pediatr Infect Dis J 2003;22:490-3.

6. Grohskopf L, Sinkowitz-Cochran R, Garrett D et al. and the Pediatric Prevention Network. A national point-prevalence survey of pediatric intensive care unit-acquired infections in the United States. J Pediatr 2002;140:432-8.

7. Asembergiene J, Gurskis V, Kevalas R, Valinteliene R. Nosocomial infections in the pediatric intensive care units in Lithuania. Medicina (Kaunas) 2009;45(1):29-36. 
8. Cavalcante SS, Mota E, Silva LR, Teixeira LF, Cavalcante LB. Risk factors for developing nosocomial infections among pediatric patients. Pediatr Infect Dis J 2006;25:438-45.

9. Özçetin M, Ulaş Saz E, Karapınar B, Özen S, Aydemir Ş, Vardar F. Hastane enfeksiyonları;sıklığı ve risk faktörleri. Çocuk Enfeksiyon Derg 2009;3:4953.

10. Ulusal Hastane Enfeksiyonları Sürveyans Ağı (UHESA) Kasım 2016. Available at:www.tmc-online.org. Accessed April 21, 2021.

11. Horan TC, Andrus M, Dudeck MA. CDC/NHSN Surveillance definition of healthcare-associated infection and criteria for specific types of infections in the acute care setting. Am J Infect Control 2008;36(5):309-32.

12. Storr J, Twyman A, Zingg W et al. and WHO Guidelines Development Group. Core components for effective infection prevention and control programmes:new WHO evidence-based recommendations. Antimicrob Resist Infect Control 2017;6:6.

13. Revelas A. Healthcare - associated infections:A public health problem. Niger Med J 2012;53(2):59-64.

14. Suetens C, Latour K, Kärki T et al. Prevalence of healthcare-associated infections, estimated incidence and composite antimicrobial resistance index in acute care hospitals and long-term care facilities:results from two European point prevalence surveys, 2016 to 2017. Euro Surveill 2018;23(46):1800516.

15. Campins M, Vaque J, Rossello' J et al. and EPINE Working Group. Nosocomial infections in pediatric patients:A prevalence study in Spanish hospitals. American Journal of Infection Control 1993;21(3):58- 63.

16. Starling CF, Couto M, Pinheiro C. Applying the Centers for Disease control and Prevention and National Nosocomial Surveillance system methods in Brazilian hospitals. Am J Infect Control 1997;25:303-6.

17. Maraş H, Somer A, Sütçü M, Acar M, Salman N. Bir Üniversite Hastanesinde Pediyatrik Sağlık Bakımı ile Illişkili Enfeksiyon Sürveyansı:Altı Aylık Prospektif İlem. Çocuk Derg 2015;15(2):65-73.

18. Gebremedhin D, Berhe H, Gebrekirstos K. Risk factors for neonatal sepsis in public hospitals of Mekelle City, North Ethiopia, 2015:unmatched case control study. PLoS One 2016;11:e0154798.

19. Klevens RM, Edwards JR, Richards $\mathrm{CL}$ et al. Estimating health careassociated infections and deaths. Public Health Rep 2007;122(2):160-6.

20. Dramowski A, Whitelaw A, Cotton MF. Burden, spectrum, and impact of healthcare-associated infection at a South African children's hospital. J Hosp Infect 2016;94(4):364-72.

21. Hacımustafaoğlu M, Çelebi S, Tuncer E, Özkaya G, Çakır D, Bozdemir ŞE. Çocuk kliniği ve çocuk yoğun bakım ünitesi hastane enfeksiyonları sıklığı. Çocuk Enfeksiyon Dergisi 2009;3:112-7.

22. Abramczyk ML, Carvalho WB, Carvalho ES, Medeiros EAS. Nosocomial infection in a pediatric intensive care unit in a developing country Braz $J$ Infect Dis 2003;7(6):375-80.

23. Bulut ME, Öncül A. Nosocomial Infection Agents of Şişli Hamidiye Etfal Training and Research Hospital:Comparison of 1995 and 2017 Data. Sisli Etfal Hastan Tip Bul 2020;54(1):78-82.

24. Kepenekli E, Soysal A, Yalindag-Ozturk N et al. and Turkish PICU-HCAI Study Group. Healthcare-Associated Infections in Pediatric Intensive Care Units in Turkey:a National Point-Prevalence Survey. Jpn J Infect Dis 2015;68(5):381-6.

25. Shang J, Stone $P, \quad$ Larson E. Studies on Nurse staffing and Healthcare Associated Infection:Methodological Challenges and Potential Solutions. Am J Infect Control 2015;43(6):581-8.

26. Stone PW. Economic burden of healthcare-associated infections:An American perspective. Expert Rev Pharmacoecon Outcomes Res 2009;9(5):417-22.

27. Yalçın S, Akalın HA, Ünal S. Hacettepe Üniversitesi Hastane İnfeksiyonlarında Antibiyotik Tedavi Illkeleri. Aktüel Tıp Derg 1983;1:448. 